\title{
The Impact of Environmental Pollution in Imo State: A Case Study of Okigwe Local Government Area
}

\author{
Adimekwe Stella Chinwe
}

Department of Mass Communication

Federal Polytechnic Oko

Anambra State, Nigeria

Doi:10.5901/jesr.2013.v3n5p79

\begin{abstract}
Environmental pollution is one of the phenomena that have gained international attention. Imo state is not an exception, hence the case of Okigwe local Government Area. This study was borne out of the inquisitives to verify the problems associated with the refuse disposal and how they affect the personal and environmental health of inhabitants. Environment concerns have become a major development issue in Nigeria as can be seen in the establish mental agency (Imsepa) and its equivalent at state levels and in all the local Governments of Imo state. Samples of 1000 people were selected using stratified random sampling. Questionnaire was employed for the data collection. Ten research questions were formulated for the study. The data collection. Using percentages. Findings from the study were discussed. Based on the findings suggestions were made on how to improve on Environmental refuse disposal for good personal and Environmental health. The suggestions were made not only to the Okigwe local Government Area but also to the society, Parents, especially women, students, school and wards of every household
\end{abstract}

\section{Introduction}

All over the world today, environment pollution is an issue of great concern because of what the environment is to human survival and indeed, the survival of the earth itself. There days, the argument on green house effect is rife everywhere in the world. "If it not green house effect", its is global warning .Both point to the fact that the earth is polluted. Williams (2006:88) affirms that it is well recognized that the environment is one of the health. He however paints out that that Nigeria suffers from both primary and secondary environmental problems resulting from underdevelopment and growth in industrialization. As a result, human Idea and activities are endangered on a daily basis. In view of these threats to the social responsibility Environmental pollination is one of Phenomenon that has gained international attention including Nigeria and I mo State hence Okigwe local Government Area. News agencies, health. Organizations, federal government's ministries of health have passed information about the menace associated with environmental pollution to the masses.

According to Encyclopedias Britannica (1978) 'pollution has been regarded as a change in the physical, chemical or biological conditions in the environment which harmfully affects the equally of life The problem of refuse disposal cum environmental pollution as regard uttering of streets with refuse materials is a crucial problem of the developing countries. Nation (1975) supporting the above statement explained that if sewage or refuse were not properly disposed they could cause serious outbreak disease which could be very harmful to human health. Some studies have shown that accumulation of solid westes is an aesthetic disasters, if they are burned, they contribute to air pollution and when rain falls percolate through them and pointes ground water suppers. 
However, a country whose citizens are suffering from plague of illness, diseases and afflictions has no place in these qualities that contribute to making any country a great nation. The mismanagement of these wastes can lead to short term risks, environmental degradation, breeding of insets, spontaneous fire outbreak

It has been observed that environmental pollution identifies improper, ineffective and unhygienic disposal of refuse materials as vectors of environmental pollution.

Some studies shows that dumping of refuse enables rats, flies and other caners of dangerous diseases to flourish and research findings have also shown that from each household turn out about a lone of rubbish a year which comprise of paper, cardboards, waste glass, damaged cars, non-cycling of scrapped cars and their components.

All these represent a source of environmental pollution involving the littering of roads with refuge, dumping of refuse on road, Sides and the conversion of drains. Other parts of the country, human faces are passed in small brushes around people's homes. The experience is the same in high density areas and urban shows where people pass faces into gutters and dump domestic waste products in the streets, blocking both drainage and vehicular passage in some places where pit latrines are used, they scarcely go with lids Apart from the stench, which exudes from such latrines, food can easily be contaminated by flies, which have their habitats there. Pollution associated with poor sanitary habits can therefore be said to be a product of underdevelopment. The environment can very well be polluted owing to social misdemeanor when people fail to observe simple public order such as where not to smoke or where not urinate. Smoking in public has been a subject of argument for along time now.

The most talk abut pollution is the industrial pollution which is now a global issue. This has generated a lot of discussions and augments at various social states especially among the scientists. gas".

While (200) notes that carbon dioxide is what environmental scientists call "a greenhouse

In Imo state, industrial plants and installations emit gasses that pollute the environment. Such pollution is always prominent in the cities where industrial activities are carried out around the clock. In an environment like this, the air and water are often polluted, while noise from industrial machines and augment create pollution of another sort.

\section{Types of Pollution}

Environmental pollution can be classified under the following headings; (i) water pollution (11) land pollution (iii) Air pollution (iv) Noise pollution.

Water pollution is the introduction into ocean waters of chemical, physical or biological material that degrades the qualities of the water. The process ranges from simple addition of dissolved or suspended solids to discharge of the most insidious toxic pollutants (such as pesticides, heavy materials and non degradable bio-accumulative, halogenated, hydrocarbons) which persist and pervade the environment. Much nipanon water are heavily polluted by human face and faucal polluted water that causes cholera.

\section{Statement of Problem}

Agricultural and industrial activities have introduced several thousand tons of toxic and hazardous chemicals into the Imo state environment precisely Okigwe local Government Area. Agro-chemicals are largely pesticides which kill or mitigate unwanted plants or animal life. Approximately, 59\% of pesticides are used as insecticides, $15 \%$ as fungicides, $15 \%$ as defoliants and herbicides , $10 \%$ as fumigants, $1 \%$ as rodenticides [Minckler 1971]. These chemicals are used by farmers to ward of pests for a their farms for a healthier crop production and the toxic effect of 
pesticide poisoning results to headaches, dizziness, nausea, vomiting, respiratory distress and eye born.

Most of the chemical wastes also led to various environmental problems that have attracted world concern such as acid rain, global warning or the green house effect or the depletion of the earths ozone layer. Most of these chemicals have either been banned or have been restricted use in developed countries hence the study looked into the impact of these chemicals on the pollution of the Imo state environment case of Okigwe local Government Area.

\section{Significance of the Study}

The study of the impact of environmental pollution will make the people of Okigwe, local Government Area especially the women to realize the importance of effective refusal disposal and waste bins and waste control. It will also be significant to people of Okigwe in a way that they will know the proper waste control strategies and how to manage and preserve the environment for the good health of the people. It will also be the people living in commercial and industrial areas of Okigwe. It will also be important so that the people will know the causes and effects of environmental in human health will not be over looked.

\section{Objective of the Study}

The objective of this study was to find out the impact of environmental pollution on the people of Okigwe local Government area of Imo state. To find out the various methods of environmental pollution control and waste disposal adopted by the people of Okigwe LGA. The reasons for management of environmental control and pool waste disposal among the people. The effects of improper pollution control and waste disposal on the environment and the possible means of controlling the phenomenon.

\section{Research Questions}

What are the various means of controlling environmental pollution in your Area?

What are the effects / impacts of improper pollution control and waste disposal in your environment?

To what extent is the pollution control agents and disposal Authority effective in Okigwe local Government Area.

What are the popular ways of controlling pollution and refuse disposal in Okigwe local Government Area.

\section{Scope of the Study / Limitations}

The study covered all the people and residents of Okigwe local Government area of Imo state. The work also covered all the twenty one autonomous communities that made up of Okigwe local Government area. The autonomous communities are Ogii, Ezinachi, Umuawaibu, Agbobu, Ihube, Umulolo, Umualumoke, Ndiokorie Orji, Ibinta, Aku, Umuze gery, Ubahu, Amuro, Aro Ogu, Isiokwe, Ugwuaku and Okigwe Urban.

The work is limited to Okigwe local Government Area because of time constraint and financial constraint. 


\section{Literature Review}

Environmental pollution means guarding all the surrounding condition which influences growth and development [air, water, land, atmosphere and space ] against pollution [DERID 2000] Udoudo[2006] observe that in some localities in Nigeria, especially among the riverine communities of the Niger Delta region, one can hardly find modern toilet facilities. In some Land pollution is the degradation of the earth's land surface through misuses of the soil by poor agricultural practices, mineral exploitation, industrial waste dumping and indiscriminate disposal of urine waters.

Air pollution is the accumulation in the atmosphere of substance that in sufficient concentration, endanger human health or produce other measured effects on living matter and other materials. Among the major sources of air pollution are powered heat generation, the burning of solid wastes, industrial processes of air pollutants are carbon monoxide from incomplete combustion engine and others are hydrocarbons, nitrogen oxides, sulphur dioxide and photochemical oxidants.

Noise pollution is a composite of sounds generated by human activities ranging from blasting stereo system to the roar of transport vehicles. The most readily measurable physiological effect of noise pollution is damage of hearing, which may be either temporary or permanent and may cause distraction of normal activities or general annoyance.

Negative impacts of environmental pollution:-

Environmental pollution has Ibreatened human existence in diverse ways. This is because life is dependence on the environment. The negative impacts of pollution in Imo state are grouped as follows:

\subsection{Negative Socio-Economic Impact:-}

The negative impact of pollution, especially from petroleum production activities has been acknowledged, Ugochukwu(2003) notes that:

Since the 1905,s petroleum operations have caused great devastation to the Niger Delta. These have impacted negatively on fishing and farming which are no longer productive enough to the era. In Ogani land food is now imported in an area once known as the food basket.

Oil spills destroy bulk farmlands and crop. They also destroy agnatic life. When a situation like this occurs, economic activities are grossly reduced and good social life hampered. Damage to farm lands and aquatic life by oil spills cannot be overstated.

Negative psychological impact:

Ashton-Jones (1998) sees environmental pollution as capable of derailing the psychological status of the citizens. Some instance of youth restiveness is in some parts of the country.

\subsection{Negative Physio-Political Impact:-}

The poor toilet facilities, smoking in the public, dumping of refuse around living houses and gas flaring. Acid rain, for example, which is the production of hydrogen chloride and sulphur dioxide which produce oxide in nitrogen in the atmosphere, can fall in solid or liquid from and it can be caused by Excessive das flaring.

\section{Environmental Impact Assessment}

The purpose of environmental impact assessment (EIA) is to provide decision makers and the public with a systematic, comprehensive and object assessment of environmental consequences of an action. This assessment is to show sufficient adverse environmental effects and to allay public fears over the consequences of such effects based on known methods of handling the effects. 


\section{Methodology}

The design of the work is survey design because e the researcher approached the study of design in which group of people is studied by collecting data from few people considered to be representative of the entire group.A sample of 1000 people was randomly selected using stratified random sample. The population consists of people from schools (351), markets (265) parents (117), Government workers (233) and Okigwe local Government Secretariat (44). The major instrument used for collecting date was questionnaire from the respondents.

The basic frame work for analysis is found in the questioner. The data collected from the respondents were analyzed using percentages.

\section{Data Analysis and Results}

The result of the study is presented in tables.

Table 1: Opinion of Respondents on environmental pollution / refuse disposal facilities, Authority effectiveness and authorized sites in Okigwe L.G.A.

\begin{tabular}{|l|c|c|c|c|}
\hline Responses & $\begin{array}{c}\text { Frequency } \\
\text { of yes }\end{array}$ & $\begin{array}{c}\text { Frequency of } \\
\text { no }\end{array}$ & No & \multirow{2}{*}{ opinion } \\
\cline { 1 - 1 } Availability of refuse & & & & \\
\hline Disposal facility & $714(71.4 \%)$ & $286(28.6 \%)$ & & - \\
\hline Refuse material & & & & - \\
\hline Disposed in authorized sites & $358(35.8 \%)$ & $642(64.2 \%)$ & & $40(40 \%)$ \\
\hline Women are affective & & & & $39(39 \%)$ \\
\hline $\begin{array}{l}\text { In refuse disposal of their } \\
\text { homes }\end{array}$ & $467(46.7 \%)$ & $493(49.3 \%)$ & & 30 \\
\hline $\begin{array}{l}\text { Refuse disposal authority is } \\
\text { effective }\end{array}$ & $413(41.3 \%)$ & $548(54.8 \%)$ & & \\
\hline
\end{tabular}

From table 1 above, out of 1000 respondents, 714 (71.4\%) indented that they have common refuse disposal facilities while $286(28.6 \%)$ indicated they have non out of 1000 respondents, $358(35.8 \%)$ indicated that was materials are dumped at authorized dumping site while $(64.4 \%)$ indicated dumping at unauthorized sites. Also $467(46.7 \%)$ indicated that women are effective in waste disposal of their homes while $493(49.3 \%)$ indicated that women are ineffective while $40(40 \%)$ indicated no opinion. Out of 1000 respondents, $413(41.3 \%)$ indicated that the waste disposal authority is effective while $548(54.8 \%)$ indicated that they are ineffective while $39(3.9 \%)$ showed no opinion.

Table 2: most popular method of waste disposal

\begin{tabular}{|l|c|c|}
\hline Response & Frequency & Percentage \\
\hline Dustbin & 487 & $48.7 \%$ \\
\hline Dumping along street & 103 & $10.3 \%$ \\
\hline Burning & 199 & $19.9 \%$ \\
\hline Disposal at authorized refuse dump & 126 & $12.6 \%$ \\
\hline Other methods & 85 & $8.5 \%$ \\
\hline Total & 1000 & $100.0 \%$ \\
\hline
\end{tabular}

Table 2 shows that out of 1000 respondents, 487 (48.7\%) indicated dustbin, 103(10.3\%) indicated dumping along the street, 199(19.9\%) indicated dumping $126(12.6 \%)$ indicated disposal at 
authorized dumping sites while $85(8.5 \%)$ indicated the refuse generated were buried in the ground.

Table 3: Agencies Responsible for waste disposal and environmental pollution control.

\begin{tabular}{|l|c|c|}
\hline Response & Frequency & Percentage \\
\hline Local Government Authority & 129 & $12.9 \%$ \\
\hline Refuse contractors & 146 & $14.6 \%$ \\
\hline Tenants & 552 & $55.2 \%$ \\
\hline Others & 173 & $17.3 \%$ \\
\hline Total & 1000 & $100.0 \%$ \\
\hline
\end{tabular}

Table 3 shows that129 respondents indicated Local Government Authority were the sole agents of environmental waste disposal control, while 146 says contractors and 552 says tenants, while 173 responded indicated other agencies like barrow pusher, kolikoli people.

\section{Discussion}

The result of this study indicated that the popular method of refuse disposal used by the respondents includes:-Dustbin, indiscriminate dumping along the streets burning which cause environmental pollution. Others include burying, indiscriminately inside gutters or close rivers or erosions.

\section{Recommendations}

Based on the result of impact of environmental pollution and refuse disposal in Okigwe Government Area, the following recommendations were made:

The authorized contractor should make sure that enough refuse contains each with cover or roof are provided at designated points along the streets.

Each house hold should keep a clean covered dustbin and stay away from noisy environment.

The Okigwe Local Government health Sector, through her health inspector should undertake routine inspection of the premises to ensure compliance by the dwellers. The council and its agent should ensure that containers are evaluated, Toilets built. They should also embark on proper environment campaign to educate the inhabitant on the dangers and impact of environmental pollution and waste disposal.

Industrialist should be warned against disposal of toxic materials in Okigwe local Area and its environments.

\section{Conclusion}

This study has indentified the problems of environmental pollution and refuse disposal and Refuse disposal and righly conclude that the people of Okigwe LGA contribute immensely to the dirty and poor refuse disposal and let all the agencies responsible for pollution control be effective.

\section{References}

Aniefioko $U$ and Ashong C [2008] "Environmental pollution and the challenge of Responsible media practice in Nigeria in communication for health and sustainable development in Nigeria, Rhyce kerex Publishers Enugu.

Ashtons Jones [2003]" covering Ethnic conflicts: An interview with silvia poggiol" in press/ politics, vol 8 no 4. 
Ochuenwike GN [2007]" Analysis of problems of refuse disposal in Pofsa Journal of Arts Oko vol. 11, No 1

Ehrillich W and Ehrilich F [1972]" Pollution Resources Environment" Issues In Human ecology, 2nd edition, Freeman and Company.

Encyclopaedia Britanica [1978], William Benton, London, vol 14.

Karish S [1980].Effective Refuse collection and Disposal, in Jos, University of Jos unpublished journal'

Nnadi G [1985]. Origin and Nature of waste, Daily Times, march 28.

Udoudo A [2006]. Newspaper coverage of Environmental Degradation in the Niger Delta" [unpublished PhD Dissertation, University of Uyo.

Ugochukwu .0.[2003]" Delivering on our mandate in the journey so far Port Harcourt: NDDC. Wile Jay [2000]" Exporting creation with physical science" Indian: Apolgia Education ministries Inc

Williams A [1992]" Nigerian Environment and national health policy" in [Towards industrial pollution Abatement in Nigeria(eds) vol. 1. Lagos: FEPA. 
